\title{
Potentiation of reward-related responding by psychostimulant infusion into nucleus accumbens: Role of dopamine receptor subtypes
}

\author{
BENSON CHU and ANN E. KELLEY \\ Northeastern University, Boston, Massachusetts
}

\begin{abstract}
The conditioned-reinforcement paradigm measures the ability of a conditioned stimulus to act as a reinforcer for newly learned operant behavior. The following experiments had two objectives. First, the effects of cocaine and pipradrol infused directly into the nucleus accumbens were assessed for their ability to potentiate responding for a conditioned reinforcer. Second, the role of D1 and D2 dopamine receptor subtypes in potentiated conditioned-reinforcement responding was examined. Cocaine (1-60 $\mu \mathrm{g})$, pipradrol (2-20 $\mu \mathrm{g})$, and amphetamine (2-20 $\mu \mathrm{g})$ all significantly enhanced conditioned-reinforcement responding when injected into the nucleus accumbens. A control experiment showed this potentiation to be dependent on the contingency between lever. pressing and the conditioned reinforcer. Pretreatment with either a D1 (SCH 23390, 0.1-mg/kg) or a D2 (raclopride, $1.0-\mathrm{mg} / \mathrm{kg}$ ) dopamine antagonist selectively reduced stimulant-potentiated responding. Direct infusion of haloperidol (1-2.5 $\mu \mathrm{g})$ into the nucleus accumbens also reduced the potentiation effect of pipradrol given systemically. Infusion of a D1 agonist (CY 208-243, 0.1-10 $\mu \mathrm{g})$ or a D2 agonist (quinpirole, $\mathbf{0 . 2 - 2 0} \mu \mathrm{g}$ ) into the nucleus accumbens did not enhance responding; however, when a combined infusion was carried out, a significant increase was noted. It is concluded that the potentiation of reward-related responding observed following dopaminergic activation of the nucleus accumbens is dependent on concurrent stimulation of both D1 and D2 receptor subtypes.
\end{abstract}

The dopaminergic innervation of the nucleus accumbens has long been considered critical for the modulation of different behaviors. Not only has its importance in motor function been established, but studies have demonstrated its role in reward processes as well. Infusions of indirect dopamine agonists directly into the nucleus accumbens increase locomotion in rats (Anden, 1977; Delfs, Schreiber, \& Kelley, 1990) and result in positive place conditioning (Carr \& White, 1983). Amphetamine, which promotes dopamine release, is directly self-administered by animals into the nucleus accumbens (Hoebel et al., 1983), although cocaine, also a stimulant drug of abuse, is not (Goeders \& Smith, 1983). Lesioning of the nucleus accumbens with the neurotoxin 6-OHDA disrupts both intravenous cocaine and amphetamine self-administration (Lyness, Friedle, \& Moore 1979; Pettit, Ettenberg, Bloom, \& Koob, 1984; Roberts, Corcoran, \& Fibiger, 1977; Roberts, Koob, Klonoff, \& Fibiger, 1980). Thus, compelling evidence implicates dopamine in the nucleus accumbens as a critical substrate for the modulation of reward mechanisms.

This work was supported by Grant DA04788 from the National Institute on Drug Abuse, and from a Ford Foundation undergraduate research award to B. Chu. Correspondence concerning this article should be addressed to Ann E. Kelley, Department of Psychology, Northeastern University, 125 Nightingale Hall, Boston, MA 02115.
Several issues arise from such studies, such as the question of why dopaminergic stimulation of the nucleus accumbens is reinforcing. Incentive-based theories (Beninger, 1983; Bindra, 1968; Robbins, Cador, Taylor, \& Everitt, 1989; Salamone, 1991) suggest that specific appetitive responses to stimuli predictive of reward develop in animals when a primary reward and a neutral environmental stimulus are paired repeatedly. Subsequently, the previously neutral stimulus becomes salient and reinforcing for the animal, and it elicits a motor response indicative of the motivational state. It has been hypothesized that psychostimulant drugs, such as amphetamine and cocaine, amplify this stimulus-response association formed by the incentive stimulus. The conditioned-reinforcement paradigm provides a useful model for studying incentive learning and stimulus-response associations. In the conditionedreinforcement paradigm, a neutral stimulus is repeatedly paired with primary reinforcement (i.e., water or food). After the conditioning phase, a novel lever is introduced, and subjects learn to leverpress for the stimulus alone without primary reward. Hill (1970), who was the first to note the effects of stimulants on responding with conditioned reinforcement, viewed this increase in responding under psychostimulant activation as the result of an increase in the reinforcing quality of the conditioned reinforcer.

Indirect dopamine agonists potentiate responding with conditioned reinforcement, an effect that is not due to 
generalized locomotor activation (Robbins, 1975, 1976, 1978). Amphetamine, a potent presynaptic dopamine releaser, potentiates responding with conditioned reinforcement when given systemically (Robbins, Watson, Gaskin, \& Ennis, 1983). The nucleus accumbens has been shown to be the site most sensitive to this effect, when intracerebral injections are carried out (Taylor \& Robbins, 1984; Kelley \& Delfs, 1991). Pipradrol, also a potent dopamine releaser, strongly potentiates responding with conditioned reinforcement when given systemically (Robbins, 1978). Cocaine also enhances responding with conditioned reinforcement when administered systemically (Beninger, Hanson, \& Phillips, 1981), although negative results have also been reported (Robbins et al., 1983). Thus, one question that derives from this work is whether pipradrol and cocaine have the ability to enhance responding with conditioned reinforcement when they are injected into the nucleus accumbens. To answer this question was the first objective of the present study.

A second matter to consider is the involvement of dopamine receptor subtypes in the potentiation effect. Sixhydroxydopamine lesions of the nucleus accumbens, which selectively abolish dopamine, reduce responding with conditioned reinforcement following intra-accumbens amphetamine administration (Taylor \& Robbins, 1986). However, little is known about the relative involvement of D1 and D2 dopamine receptor subtypes. Since the role of dopamine receptor subtypes in reward processes has been the focus of a number of recent studies (for reviews, see Beninger, Hoffman, \& Mazurski, 1989; Nakajima, 1989), it appeared to be of interest to investigate this role in the conditioned reinforcement paradigm. For the antagonists, the D1-selective agent SCH 23390 (Iorio, Barnett, Leitz, Houser, \& Kordoba, 1983) and the D2-selective agent raclopride (Hillegaart \& Ahlenius, 1987) were used. For the D2-selective agonist, quinpirole was used (Fuller \& Hemrick-Luecke, 1985). The D1-selective agonist presented a problem, because the most commonly used D1 agonist, SKF 38393, has been shown to cause neurotoxicity when directly injected into the brain (Kelley, Delfs, \& Chu, 1990). Thus, an alternative D1-selective drug, CY 208-243, was employed (Markstein et al., 1988; Murray \& Waddington, 1990).

\section{METHOD}

\section{Animals and Surgery}

The subjects were 68 male Sprague-Dawley rats (Charles River Laboratories, Wilmington, MA). Upon their arrival in the lab, the rats were handled in order to habituate them to the new environment and weighed. Subsequently, they were housed individually in transparent plastic cages with wire grid floors; the cages were kept in a colony room (lights on $0800-2000 \mathrm{~h}$ ). Food was ad lib for the first few days; it was removed when the animals weighed about 310-320 g. The rats were then placed on a food-restricted diet and maintained at $80 \%$ of free-feeding weight. Water was available ad lib throughout the experiment.

For surgery (which took place after initial training; see below), subjects were anesthetized with Nembutal anesthesia $(50 \mathrm{mg} / \mathrm{kg})$, and bilateral indwelling cannulae were implanted according to stan- dard stereotaxic procedures. Coordinates were determined on the basis of the atlas of Pellegrino and Cushman (1967) (in millimeters, with the toothbar $5 \mathrm{~mm}$ above the interaural zero). Coordinates for the nucleus accumbens were as follows (in millimeters): anteroposterior plane (A-P), +3.5 from bregma; mediolateral (M-L), \pm 1.7 from midline; dorsoventral (D-V), -5.7 from skull surface. Stainless steel cannulas guides (23 gauge) were aimed $2.5 \mathrm{~mm}$ above the injection site in the nucleus accumbens. The guides were af fixed to the skull with stainless steel mounting screws and lightcurable dental resin. Wire stylets were inserted into the guides to prevent occlusion. The rats were allowed a minimum of 2 days for recovery. Following this period, they were trained for several more sessions before infusions began (see below).

\section{Drugs and Microinfusion}

D-amphetamine sulfate, cocaine hydrochloride (Sigma, St. Louis), pipradrol HCL (Merrell Dow Research, Cincinnati), SCH 23390, raclopride, quinpirole (Research Biochemicals, Natick, MA), and CY 208-243 (Sandoz, East Hanover, NJ) were dissolved in 0.9\% saline. The injectable form of haloperidol (Quad Pharmaceuticals, Indianapolis) was used. The intracerebral injection procedure consisted of holding subjects loosely in a towel. The stylets were removed, and the cannulae guides were cleaned with a square precut dental broach. Bilateral injection cannulae ( $30 \mathrm{ga})$ were then lowered through the guides to the desired site. The injection cannulae were connected via polyethylene tubing (Clay Adams, Parsippany, NJ) to a microdrive pump (Harvard Apparatus, South Natick, MA). All infusions were bilateral in a volume of $1.0 \mu \mathrm{l}$ over a period of $2 \min 0 \mathrm{sec}$ with $1 \mathrm{~min}$ of diffusion time. At the end of the infusion, the stylets were replaced. One day before actual experimental testing, a preliminary saline injection was given to the subjects in order to habituate them to the procedure.

\section{Behavioral Testing Procedure}

The apparatus consisted of eight operant chambers (Coulbourn Instruments), each housed in a sound-attenuating plastic chamber with a peephole in the door. The chambers were equipped with a food magazine, which delivered food pellets ( $45 \mathrm{mg}$, BioServ) to the subject. White noise was used in order to minimize extraneous noise. A lever could be located on either the left or the right of the food hopper. A photocell located in the food hopper measured nose pokes. A houselight and a panel of three lights were also situated above the hopper. All operant schedules and lever responses were controlled and collected by a Eurobeeb microcomputer (Paul Fray Ltd., Cambridge, England).

Initially, the food-deprived rats were given a $10-\mathrm{min}$ session in the chamber with one lever in the box, either on the right or left. The position of the lever was held constant for each subject. Food pellets were also placed in the hopper so that the subjects would become accustomed to receiving food there. The levers were then removed for the duration of the training phase. A classical conditioning paradigm was employed, in which the subjects were trained to associate the delivery of a food reinforcer with a compound stimulus. The compound stimulus, preceding food delivery, consisted of houselights off, red panel light on (3-sec duration), and the click of the food magazine (1-sec duration). In order to prevent the subject from keeping its head in the hopper, a 3-sec delay in the next possible delivery of reinforcement was introduced if subjects nose poked prematurely. Initial training consisted of a random-time 10sec reinforcement schedule, with the compound stimulus and food presented on the average every $10 \mathrm{sec}$. Training consisted of progressively increasing the schedule to a random-time 30-sec schedule, with food made available on the average every $30 \mathrm{sec}$. The subjects were trained daily for approximately $30 \mathrm{~min}$. After the subjects' performance stabilized, usually after three to five sessions with the random-time $30-\mathrm{sec}$ schedule, the subjects were operated upon. Stable performance was usually indicated by a decrease in 
the number of premature nose pokes into the food hopper, as well as immediate response to all food reinforcements. After recovery from surgery, the rats were given additional training-approximately three sessions with the random-time 30 -sec schedule.

For the testing phase, the lever was reintroduced into the box. Presentation of the compound stimulus, but no food, was contingent on a leverpress. In a preliminary session, each subject was allowed to press the lever at least 10 times (to make certain they sampled the contingency and acquired the response), after which the subject was removed. In actual test sessions, the first 10 responses were reinforced with the compound stimulus, after which all other responses were reinforced with the probability of 0.5 . A series of test sessions was then conducted. Test days were one day apart. All microinjections of different doses or treatments were administered in a counterbalanced manner, with each subject serving as its own control. Following intracerebral injection, the subjects were introduced into the chamber for a 45 -min session, starting at the first leverpress. For the subjects that received cocaine, there was a 10 -min period between injection and introduction into the operant chamber. Responses and nose pokes were recorded automatically. Observations could be made through a peephole in the side of each chamber.

\section{Experiments}

Six experiments were carried out.

Experiment 1. Cocaine $(0,1.0,10.0,30.0$, or $60.0 \mu \mathrm{g} / \mu \mathrm{l})$ was infused into the nucleus accumbens in 13 subjects. Doses were counterbalanced across the five test days. These doses were chosen on the basis of the dose-response curve obtained in a previous study (Delfs et al., 1990).

Experiment 2. Amphetamine $(0,0.2$, or $20.0 \mu \mathrm{g} / \mu \mathrm{l})$ was infused $(N=8)$ into the nucleus accumbens on Test Days 1, 2, and 3 (doses counterbalanced). On Test Days 4, 5, and 6, rats were pretreated with intraperitoneal (i.p.) saline $(1 \mathrm{ml} / \mathrm{kg})$, raclopride $(1 \mathrm{mg} / \mathrm{kg})$, or SCH $23390(0.1 \mathrm{mg} / \mathrm{kg})$ in combination with a $20.0-\mu \mathrm{g} / \mu \mathrm{l} \mathrm{am}-$ phetamine microinfusion into the nucleus accumbens. Pretreatments were counterbalanced over the test days and were administered 30 and $40 \mathrm{~min}$ before intracerebral injection for raclopride and $\mathrm{SCH}$ 23390 , respectively.

Experiment 3. Pipradrol $(0,2.0,10.0$, or $20.0 \mu \mathrm{g} / \mu \mathrm{l})$ was infused into the nucleus accumbens, counterbalanced across the first 4 days $(N=8)$. On Test Days 5,6 , and 7 , rats were pretreated i.p. with saline $(1 \mathrm{ml} / \mathrm{kg})$, raclopride $(1 \mathrm{mg} / \mathrm{kg})$, or SCH 23390 $(0.1 \mathrm{mg} / \mathrm{kg})$ in combination with $10.0-\mu \mathrm{g} / \mu \mathrm{l}$ pipradrol into the nucleus accumbens. Pretreatments were counterbalanced over the test days and were administered 30 or $40 \mathrm{~min}$ before intracerebral injection for raclopride and SCH 23390 , respectively.

Experiment 4. In this experiment, pipradrol was injected systemically $(10 \mathrm{mg} / \mathrm{kg}$, i.p.), and rats were pretreated with haloperidol injections into the nucleus accumbens. Doses of haloperidol $(0,1.0$, or $2.5 \mu \mathrm{g}$ ) were administered in a counterbalanced manner. The doses of pipradrol and haloperidol were chosen on the basis of previous work (Delfs \& Kelley, 1990; Robbins, 1978).

Experiment 5. This experiment consisted of three parts. In one group $(N=8)$, the effect of infusion of the D1 agonist CY 208$243(0,0.1,1.0$, or $10.0 \mu \mathrm{g} / \mu \mathrm{l})$ into the nucleus accumbens was assessed on responding for conditioned reinforcement. In a separate group $(N=8)$, quinpirole $(0,0.2,2.0$, or $20.0 \mu \mathrm{g} / \mu \mathrm{l})$ was infused into the nucleus accumbens. At the conclusion of both experiments, amphetamine was administered intracerebrally as a comparison drug. So that we could examine the hypothesis of synergism between D1 and D2 receptor subtypes, a third group $(N=8)$ received intra-accumbens infusions of both D1 and D2 agonists. For this experiment, the dose of CY 208-243 was kept constant, while the dose of quinpirole was varied. Treatments (counterbalanced across days) consisted of saline; $0.2 \mu \mathrm{g} / \mu \mathrm{l}$ quinpirole + $1 \mu \mathrm{g} / \mu \mathrm{l} \mathrm{CY} 208-243 ; 2.0 \mu \mathrm{g} / \mu \mathrm{l}$ quinpirole $+1 \mu \mathrm{g} / \mu \mathrm{l} \mathrm{CY} 208-243$; and $20.0 \mu \mathrm{g} / \mu \mathrm{l}$ quinpirole $+1 \mu \mathrm{g} / \mu \mathrm{l} \mathrm{CY} 208-243$.
Experiment 6. In the final experiment, the hypothesis that potentiated responding for conditioned reinforcement was due to nonspecific motor activation was examined. In this experiment, animals were trained according to standard procedure. However, for the test days, leverpressing had no programmed consequence. Subjects $(N=8)$ received intra-accumbens infusions of the drugs saline, cocaine $(30 \mu \mathrm{g} / \mu \mathrm{l})$, amphetamine $(20 \mu \mathrm{g} / \mu \mathrm{l})$, or pipradrol $(10 \mu \mathrm{g} / \mu \mathrm{l})$, in a counterbalanced order. The doses chosen had enhanced responding to the greatest extent in previous experiments.

\section{Statistics}

Analysis of the data was carried out with an IBM-compatible statistical software package (CRISP Interactive Statistical Package). All analyses were carried out with one-factor analyses of variance (ANOVA), with dose (or treatment) as the factor and the leverpress as the dependent variable. Post hoc comparisons were carried out, using Newman-Keuls comparisons between means (Bruning $\&$ Kintz 1977). In some cases, a paired Student's $t$ test was conducted.

\section{Histology}

After the experiment, subjects were deeply anesthetized with Nembutal and perfused transcardially with isotonic saline and a $\mathbf{1 0 \%}$ formalin solution to fix the brain in situ. Their brains were then removed and stored for several days in a $30 \%$ sugar formalin solution. Subsequently, the brains were sectioned, mounted, and stained with cresyl violet to confirm the location of cannulae tracks. Ex amples of sections depicting cannulae placements are shown in Figure 7.

\section{RESULTS}

\section{Experiment 1 \\ Effect of Cocaine Infusion on \\ Conditioned-Reinforcement Responding}

Intra-accumbens infusions of cocaine $(0,1.0,10.0$, 30.0 , or $60.0 \mu \mathrm{g} / \mu \mathrm{l}$ ) resulted in a dose-dependent potentiation in responding for conditioned reinforcement (Figure 1). The highest response levels occurred at the 30.0$\mu \mathrm{g}$ dose; levels dropped off at lower and higher doses. Overall, the ANOVA indicated a significant effect of dose $[F(4,48)=2.7, p<.041]$. A post hoc Newman-Keuls analysis revealed that responding following the $30-\mu \mathrm{g}$ dose alone was significantly higher than that following saline $(p<.05)$. It should be noted that overall levels of re-

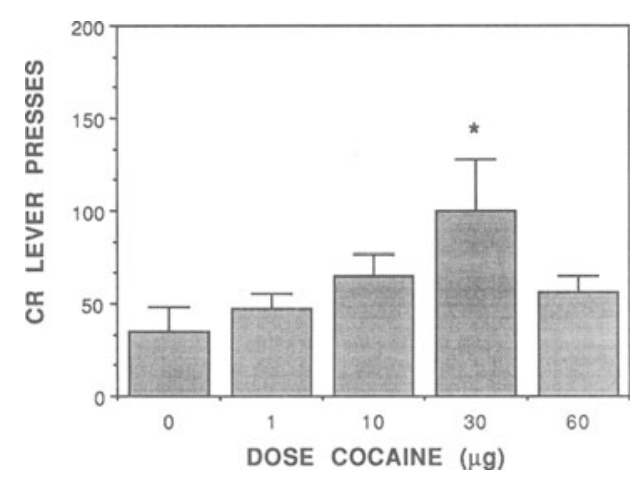

Figure 1. Effect of cocaine infused into nucleus accumbens on responding with a conditioned reinforcer (CR). Bars represent mean \pm SEM. ${ }^{*} p<.05$. 


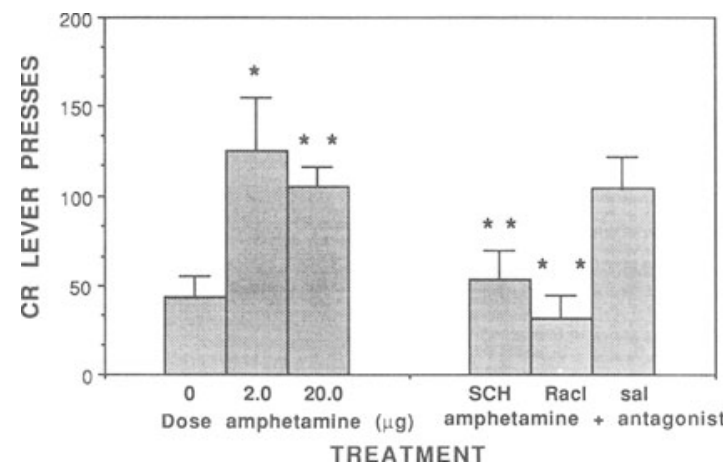

Figure 2. Left: Effect of amphetamine infused into the nucleus accumbens on responding for a conditioned reinforcer (CR). Right: Rats were pretreated systemically (i.p.) with SCH 23390 (SCH) or raclopride (Racl) or saline (sal), in conjunction with amphetamine $(20 \mu \mathrm{g})$ in the nucleus accumbens. Bars represent mean $\pm S E M$. ${ }^{*} p<.05 .{ }^{* *} p<.01$.

sponding were somewhat less than those observed following infusions of the dopamine releasing agents amphetamine and pipradrol.

\section{Experiment 2}

\section{Amphetamine Infusion and Pretreatment} With D1 and D2 Antagonists

Intra-accumbens amphetamine $(0,2.0$, and $20.0 \mu \mathrm{g} / \mu \mathrm{l})$ infusion resulted in a significant increase in responding for the conditioned reinforcer, relative to baseline (Figure 2). Both doses of amphetamine significantly elevated responding for the conditioned reinforcer overall $[F(2,14)$ $=8.166]$. The augmentation was significant at both the $2.0-\mu \mathrm{g}$ dose $(p<.01$, Newman-Keuls $)$ and the $20.0-\mu \mathrm{g}$ dose $(p<.05)$.

In the second part of this experiment, both dopamine antagonists significantly decreased response levels relative to saline pretreatment (Figure 2). The ANOVA indicated an overall treatment effect $[F(2,14)=5.067, p<$
.0219]. A post hoc Newman-Keuls analysis revealed that both dopamine antagonist pretreatments significantly reduced responding relative to pretreatment with saline $(p<.05)$. A paired $t$ test revealed no statistical difference between both pretreatment conditions and the intraaccumbens saline condition alone (for SCH 23390, .05 < $p<.627$; for raclopride, $.05<p<1$ ). Table 1 shows that although nose poking was somewhat reduced by neuroleptic treatment, there was no significant effect.

\section{Experiment 3 Pipradrol Infusion and Pretreatment With D1 and D2 Antagonists}

Intra-accumbens pipradrol $(0,2.0,10.0$, or $20.0 \mu \mathrm{g} / \mu \mathrm{l})$ infusion resulted in a significant dose-dependent increase in responding for conditioned reinforcement (Figure 3). Overall, the ANOVA indicated a significant effect of dose $[F(3,21)=5.771, p<.0048]$. A post hoc test revealed that responding following all doses was significantly elevated over baseline responding $(2.0 \mu \mathrm{g}, p<.05 ; 10.0 \mu \mathrm{g}$, $p<.01 ; 20.0 \mu \mathrm{g}, p<.01)$.

After the completion of the initial four doses, the effects of dopamine antagonists were tested. Both dopamine antagonists significantly decreased response levels relative to the effects of intra-accumbens pipradrol in conjunction with i.p. saline (Figure 3). The ANOVA indicated an overall treatment effect $[F(3,21)=8.428, p<$ $.0007]$. Both SCH 23390 and raclopride pretreatments decreased response levels to baseline levels. A post hoc analysis revealed that both pretreatments significantly reduced responding relative to intra-accumbens $10-\mu \mathrm{g}$ pipradrol with saline pretreatment $(p<.05$ for SCH 23390; $p<$ .01 for raclopride). Furthermore, response levels for $\mathrm{SCH}$ 23390 and raclopride were comparable to response levels following saline infusion into the accumbens alone (paired $t$ test: for SCH 23390, .05 $<p<1$; for raclopride, $.05<p<.519)$. Table 1 shows that treatment with the neuroleptics did not affect nose poking.

Table 1

Nose Pokes Into Food Tray Following Treatment With Various Dopamine Antagonists

\begin{tabular}{|c|c|c|c|}
\hline \multirow[b]{2}{*}{ Treatment } & \multicolumn{2}{|c|}{ Nose Pokes } & \multirow[b]{2}{*}{$F$ Ratio } \\
\hline & $M$ & $S E M$ & \\
\hline \multicolumn{4}{|l|}{$\begin{array}{l}\text { Experiment } 2 \\
\text { (amphetamine in N.Acc.) }\end{array}$} \\
\hline SCH 23390 i.p. & 67 & 20 & \\
\hline raclopride i.p. & 80 & 21 & $F(2,14)=2.8, .05<p<.09$ \\
\hline saline i.p. & 124 & 31 & \\
\hline \multicolumn{4}{|l|}{$\begin{array}{l}\text { Experiment } 3 \\
\text { (pipradol in N.Acc.) }\end{array}$} \\
\hline SCH 23390 i.p. & 43 & 13 & \\
\hline raclopride i.p. & 32 & 11 & $F(2,14)=2.4, .05<p<.12$ \\
\hline saline i.p. & 69 & 12 & \\
\hline \multicolumn{4}{|l|}{$\begin{array}{l}\text { Experiment } 4 \\
\text { (pipradol i.p.) }\end{array}$} \\
\hline saline/N.Acc. & 56 & 23 & \\
\hline $1.0 \mu \mathrm{g}$ haloperidol/N.Acc. & 90 & 32 & {$[F(2,12)=0.3, .05<p<.7$} \\
\hline $2.5 \mu \mathrm{g}$ haloperidol/N.Acc. & 79 & 26 & \\
\hline
\end{tabular}




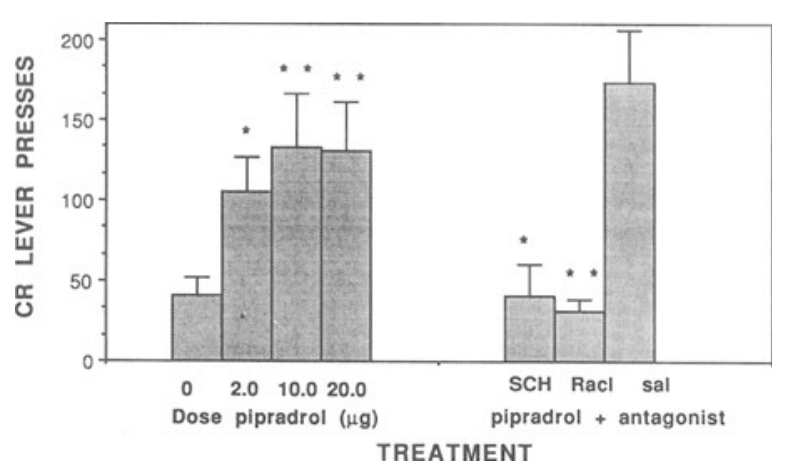

Figure 3. Left: Effects of pipradrol infused into nucleus accumbens on responding for a conditioned reinforcer (CR). Right: Rats were pretreated with SCH 23390 (SCH), raclopride (Racl), or saline (sal), in conjunction with pipradrol $(10 \mu \mathrm{g})$ in the nucleus accumbens. Bars represent mean $\pm S E M .{ }^{*} p<.05$. ${ }^{* *} p<.01$.

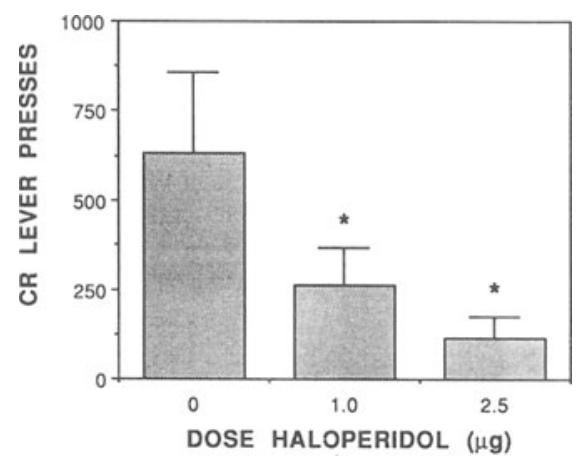

Figure 4. Pipradrol-induced potentiated responding for a conditioned reinforcer (CR) is reduced by haloperidol pretreatment in the nucleus accumbens. Rats were treated with 10-mg/kg pipradrol (i.p.). Bars represent mean $\pm S E M .{ }^{*} p<.05$.

\section{Experiment 4}

Effect of Intra-Accumbens Haloperidol

Infusion on Pipradrol-Enhanced

Conditioned-Reinforcement Responding

Figure 4 shows the results of this experiment. As can be observed, pipradrol markedly potentiated conditionedreinforcement responding (to a greater degree than that noted following intracerebral injection). Concurrent intraaccumbens haloperidol dose dependently reduced conditioned-reinforcement responding $[F(2,12)=5.3, p<$ $.02]$. Both doses of haloperidol significantly reduced responding, compared with saline $(p<.05)$. Table 1 shows that intra-accumbens haloperidol had no effect on nosepoking behavior.

\section{Experiment 5}

Effect of D1 and D2 Agonist Infusion on

Conditioned-Reinforcement Responding

Intra-accumbens infusions of CY 208-243 failed to significantly enhance responding for conditioned reinforcement $[F(4,28)=2.513, .05<p<.0635]$. As can be seen in Figure 5A, CY 208-243 actually tended to de- crease responding from baseline. Intra-accumbens amphetamine infusion enhanced responding over baseline, although the effect did not reach significance. The ANOVA did, however, reveal that responding under amphetamine approached significance when compared with the $0.1-$ and $10.0-\mu \mathrm{g}$ doses of CY 208-243 (Newman-Keuls, $p<.1$ ).

Intra-accumbens infusions of quinpirole (Figure 5B) also failed to significantly elevate responding for conditioned reinforcement, although amphetamine-potentiated responding did $[F(4,24)=4.243, .05<p<.0097]$. A post hoc Newman-Keuls analysis revealed that responding
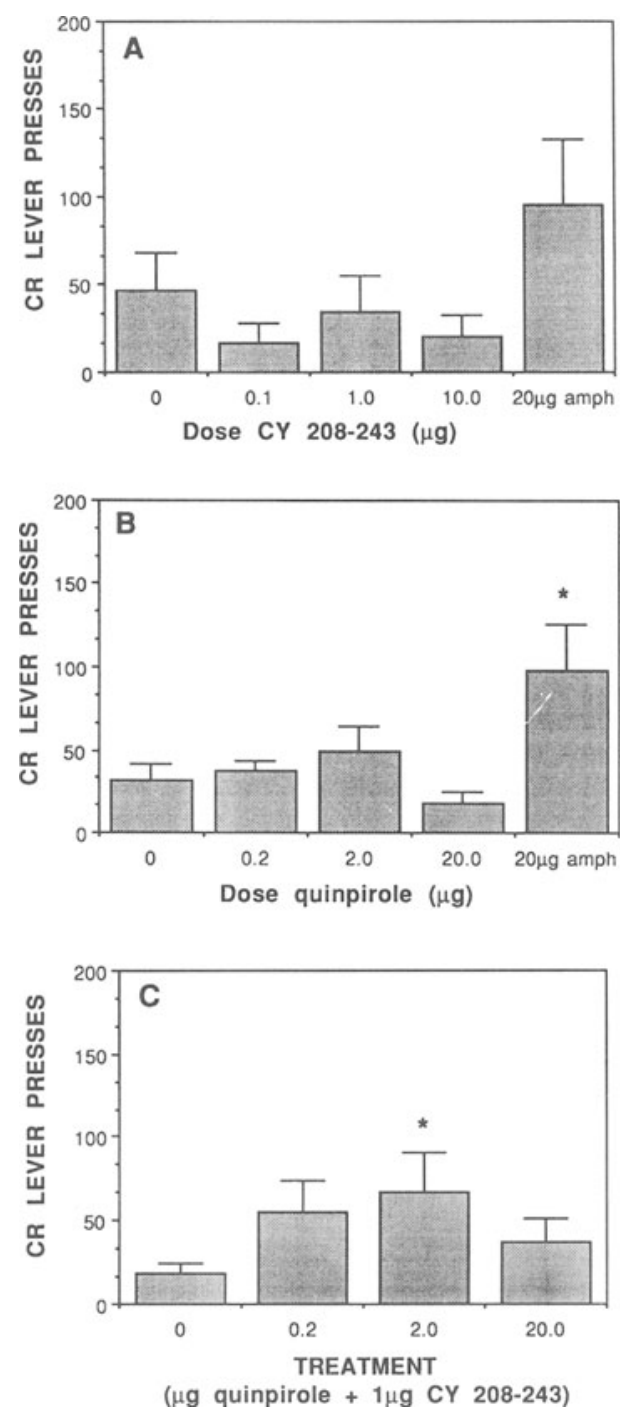

Figure 5. Effects of direct dopamine agonists infused into nucleus accumbens on responding for a conditioned reinforcer (CR). (A) Effect of the D1 agonist CY 208-243. Far right bar is effect of amphetamine given on the last test day. (B) Responding following infusion of the D2 agonist quinpirole into nucleus accumbens, on the last test day animals were injected with amphetamine. Bars represent mean $\pm S E M$. ${ }^{*} p<.05$. (C) Responding following infusion of combined D1 and D2 agonist. CY 208-243 dose was held constant at $1 \mu \mathrm{g}$ and the quinpirole dose was varied. Bars represent mean \pm SEM. $p<.05$. 


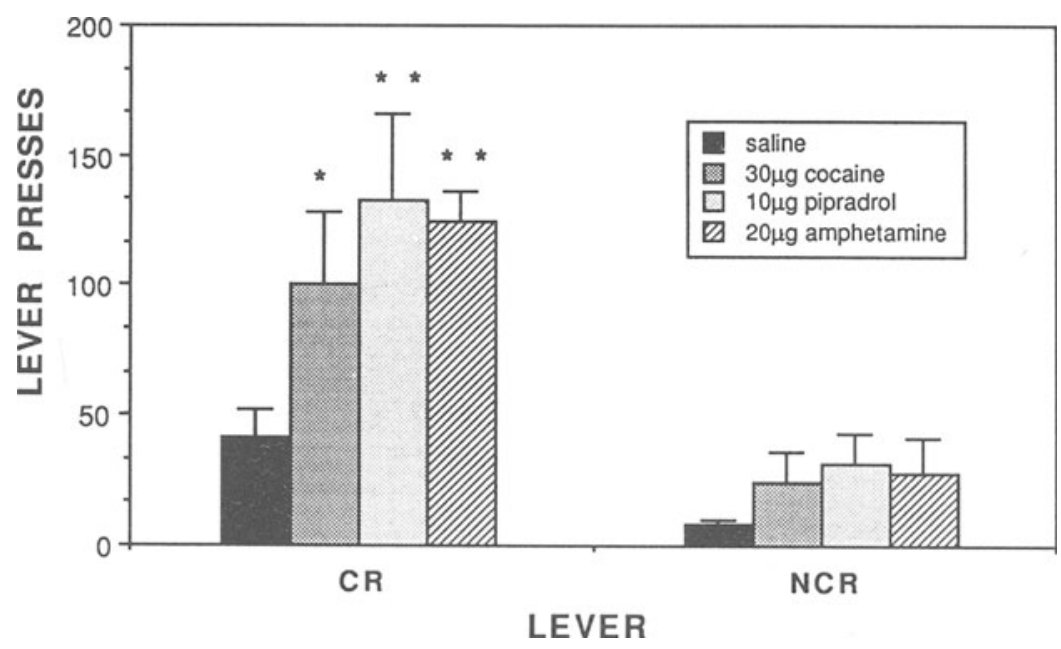

Figure 6. Motor control experiment. Left: Results from Experiments 1, 2, and 3, at the doses that were most effective in potentiating responding. Right: Leverpressing when equivalent doses were injected; but leverpressing did not result in presentation of the conditioned reinforcer (NCR). CR, conditioned reinforcer. Bars represent mean $\pm S E M .{ }^{*} p<.01$.

under amphetamine was significantly higher in comparison with baseline and all quinpirole conditions $(p<.05)$.

Concurrent injection of CY 203-243 and quinpirole resulted in significantly enhanced responding (Figure 5C). The ANOVA indicated an overall treatment effect $[F(3,21)$ $=3.754, p<.0262]$. Post hoc analysis revealed that responding for conditioned reinforcement was significantly elevated by the $2.0-\mu \mathrm{g} / \mu \mathrm{l}$ quinpirole $+1.0-\mu \mathrm{g} / \mu \mathrm{l} \mathrm{CY} 208-$ 243 treatment $(p<.05)$ as opposed to the saline control. Note however, that the magnitude of the effect was considerably lower than that observed with indirect agonists.

\section{Experiment 6 \\ Effect of Intra-Accumbens Dopamine Agonist \\ Infusion on Noncontingent Leverpressing}

An ANOVA revealed no significant increase in responding after amphetamine, pipradrol, or cocaine when responding did not provide the conditioned-reinforcement stimulus $[F(3,21)=1.151, .05<p<.3481]$. However, a few rats showed increases in responding following different drugs (see Figure 5). Although the motor stimulating effects of these drugs occasionally increased responding, no consistent effect was noted.

\section{DISCUSSION}

Past evidence has suggested that the nucleus accumbens is critical for the expression of various reward-related behaviors, such as responding for conditioned reward (for a review, see Robbins et al., 1989). Our present observation that the intra-accumbens infusion of amphetamine potentiates responding with conditioned reinforcement extends and confirms previous results (Kelley \& Delfs, 1991; Taylor \& Robbins, 1984, 1986).
In light of such evidence, the nucleus accumbens seemed a likely candidate to mediate the responsepotentiating effects of two other psychoactive agents, pipradrol and cocaine. Our present findings show that intra-accumbens infusion of cocaine can indeed selectively enhance conditioned-reinforcement responding. Although cocaine does induce motor activation when injected into this structure (Delfs \& Kelley, 1990), the "motor control" experiment (Experiment 6) showed that leverpressing was not significantly enhanced when it did not provide the conditioned reinforcement. It is interesting that a positive effect was found, since cocaine given systemically has resulted in inconsistent effects in this paradigm. Robbins and colleagues (Robbins et al., 1983) did not report enhanced responding following systemic cocaine, although cocaine analogues were found to strongly potentiate responding. Another report did show conditionedreinforcement-enhancing properties of systemic cocaine (Beninger et al., 1981; cf. Phillips \& Fibiger, 1990). Note that responding was less robust under cocaine than under either amphetamine or pipradrol. This may be due to the highly lipophilic properties of cocaine; it may diffuse very quickly away from the active site. Clearly, much higher doses (than those of amphetamine or pipradrol) were needed to obtain even a weak effect. Also, the effects that cocaine exerts on other neuronal systems, as well as its local anesthetic properties, may interfere with the responseenhancing effects. It is noteworthy that amphetamine is much more potent than cocaine in inducing dopamine overflow, as measured by dialysis (Hurd \& Ungerstedt, 1989).

The observation that pipradrol also enhances responding with conditioned reinforcement when infused directly into the nucleus accumbens suggests that amphetamine and pipradrol act on a common neurochemical substrate. Max- 

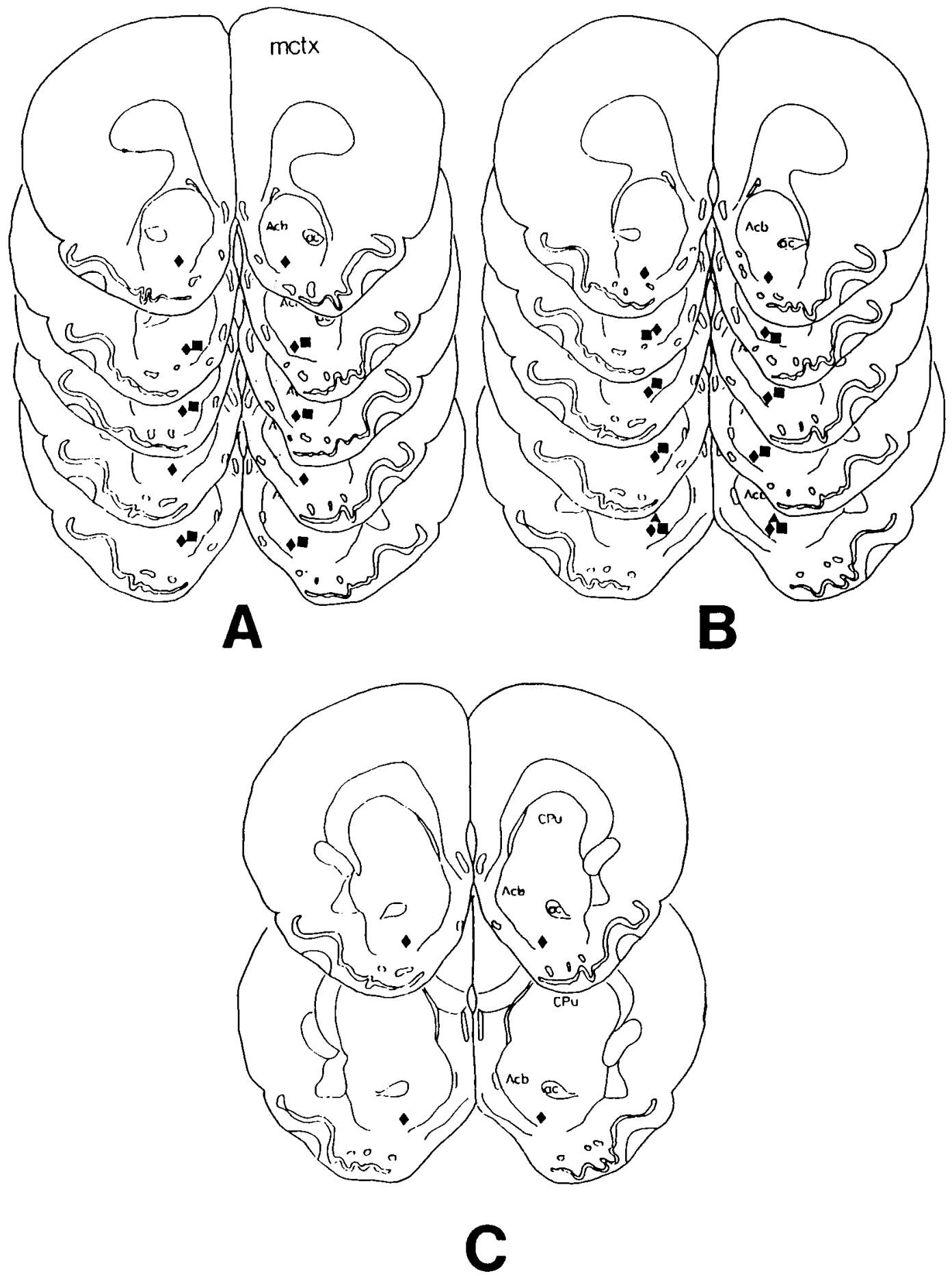

Figure 7. Representative coronal sections depicting cannula placement within nucleus accumbens. (A) Representative placements from Experiments 1 and 2. (B) Representative plocements from Experiment 5. (C) Representative placements from Experiment 6. 
imum mean response levels following either amphetamine or pipradrol intra-accumbens administration were similar (approximately 125-150 conditioned-reinforcement responses/session). Systemically, pipradrol is the most potent agent for enhancing conditioned-reinforcement responding (Beninger et al., 1981; Robbins et al., 1983). Pipradrol also enhances responding for a stimulus previously associated with brain-stimulation reward (Robbins \& Koob, 1978). Older biochemical studies show that pipradrol is a potent releaser of dopamine (Scheel-Kruger, 1971); however, microdialysis work has not yet been carried out with this compound. The findings that haloperidol infusion into nucleus accumbens dose-dependently reduces potentiated responding provides additional evidence that the nucleus accumbens is the substrate for the pipradrol effect.

A question examined in this work concerns the relative roles of dopamine receptor subtypes in responding for conditioned reward. The present data suggest that activation of both D1 and D2 receptor subtypes is necessary for stimulant-induced potentiation of conditionedreinforcement responding. Systemic pretreatment with either a D1 (SCH 23390) or a D2 (raclopride) antagonist reduced both amphetamine and pipradrol response levels to baseline (Figures 2 and 3). Note that response levels following SCH 23390 or raclopride pretreatment were comparable to baseline responding, indicating that motor performance deficits were probably not an important factor in the effect. Further evidence against obvious motor deficits is provided by the lack of an effect of the neuroleptics on nose-poking behavior. Thus, it appears that pretreatment with the dopamine antagonists selectively reduced the ability of the stimulants to potentiate responding for a rewarding stimulus.

The current literature on effects of selective antagonists suggests that both receptor subtypes play some role in reward-related behavior (for reviews, see Beninger, et al., 1989; Nakajima, 1989). Antagonism of either D1 or D2 receptors effectively blocks the development of amphetamine-induced place preference (Beninger et al., 1989; Hiroi \& White, 1991). There is ample evidence that D2selective blockers antagonize stimulant self-administration (e.g., Ettenberg, Pettit, Bloom, \& Koob, 1982; Yokel \& Wise, 1976), and D1-selective antagonists also reduce this behavior (Koob, Le, \& Creese, 1987; Woolverton \& Virus, 1989). Barpressing for brain stimulation is reduced by both SCH 23390 and raclopride (Nakajima \& Baker, 1989).

Work with selective agonists further suggests that D2 receptors are critical, whereas D1 receptors are "enabling"' (Clark \& White, 1987). For example, D2 agonists are self-administered and induce positive place conditioning (Hoffman \& Beninger, 1989; Hoffman, Dickson, \& Beninger, 1988), whereas Dl agonists are not active in either paradigm and actually cause a place aversion (White, Packard, \& Hiroi, 1991; Woolverton, Goldberg, \& Ginos, 1984). On the other hand, stimulation of D1 receptors is necessary for the expression of D2 behavioral and electrophysiological effects (Dreher \& Jackson, 1989; Longoni, Spina, \& Di Chiara, 1987; Molloy, O’Boyle, Pugh, \& Waddington, 1986; Walters, Bergstrom, Carlson, Chase, \& Braun, 1987; White, 1987). In our laboratory, we have found that full expression of dopaminestimulated oral stereotypy elicited from the ventrolateral striatum is dependent on concurrent stimulation of both receptor subtypes (Delfs \& Kelley, 1990).

The present results from the use of selective agonists agree with this general theory. Although the intraaccumbens infusion of either CY 208-243 or quinpirole alone was insufficient to increase responding with conditioned reinforcement, the simultaneous infusion of the two agonists was effective in increasing responding. The data suggest that the enhancement was due to a synergistic rather than an additive effect. CY 208-243 actually tended to decrease responding from baseline, whereas quinpirole infusion tended to elevate pressing at two of the doses used. Therefore, if the result were a product of an addition of the two independent effects, responding under the combined infusion should be about the same as baseline. Responding under the combined treatment was higher than baseline and higher than responding with quinpirole alone, indicating a synergistic effect.

It should be emphasized that leverpressing following administration of the combined agonists was lower than that observed following administration of dopaminereleasing drugs such as amphetamine and pipradrol; this is consistent with past work. In contrast to effects with indirect dopamine agonists, apomorphine does not selectively enhance conditioned-reinforcement responding (Beninger et al., 1989; Robbins et al.), and dopamine itself, when infused into nucleus accumbens, does so only weakly and in high doses (Cador, Taylor, \& Robbins, in press). It has been suggested that in the conditionedreinforcement paradigm, the reward signal, indicative of past learning, is dependent on incoming information from corticolimbic structures (Cador, Robbins, \& Everitt, 1989). The signal may be preserved (and perhaps enhanced) by indirect dopamine agonists, which act presynaptically. In contrast, direct stimulation of postsynaptic dopamine receptors may actually mask or disrupt the reward signal (Beninger et al., 1989; Robbins \& Everitt, 1982). Thus, although some synergism and enhancement was observed with the combination of agonists, this may be a weak or even a nonspecific effect. It should be noted that the lack of effect with quinpirole alone does not agree with the finding that D2 agonists administered systemically (quinpirole and bromocriptine) do enhance conditioned-reinforcement responding (Beninger et al., 1989). At present, we do not have an explanation for this discrepancy, although it is nonetheless clear that stimulation of D2 receptors is necessary for expression of rewardrelated responding.

Since SKF 38393 had been previously shown to be neurotoxic when injected into the brain (Kelley et al., 1990), the lack of a suitable D1 receptor agonist necessitated the use of CY 208-243. Several in vitro binding studies have 
questioned the selectivity of CY 208-243 as a D1 agonist (Andersen \& Jansen, 1990; Murray \& Waddington, 1990). On the other hand, the D1 agonist properties of CY 208243 have been demonstrated in behavioral studies; functionally, it resembles a D1 agonist (Dreher \& Jackson, 1989; Murray \& Waddington, 1990; Temlett, Chong, Oertel, Jenner, \& Mardsden, 1988). Thus, it appears that in functional terms it may be a suitable compound for intracerebral work. No neurotoxic effects were observed in rats treated with CY 208-243.

One final issue arises-namely, the present design of the conditioned-reinforcement paradigm. Previously, this paradigm has been conducted with two levers in the same box, one providing the conditioned reinforcer and the other being a control lever. We have found that the shortcoming of the two-lever design consists in response generalization; under the effects of a stimulant, a considerable number of animals do not discriminate between the two levers, and this increases variability in the data substantially. The one-lever design eliminates this problem but necessitates the use of a motor control experiment. The control experiment showed the response-reinforcer association to be critical for a true potentiation to occur. However, it was clear that responding under amphetamine, pipradrol, or cocaine was elevated over baseline, although not significantly. The increase in mean leverpresses was usually attributable to 1 or 2 subjects. These drug-induced increases in responding may be due to nonspecific increases in general activity. These results are consistent with two-lever studies that have resulted in dose-dependent increases on the control lever (Kelley \& Delfs, 1991; Taylor \& Robbins, 1984).

In conclusion, amphetamine, cocaine, and pipradrol injected into the nucleus accumbens potentiate responding for reward-related stimuli. The enhancement of responding observed following the dopamine-releasing agents is due to activation of both D1 and D2 receptors. It is likely that synergistic activation of both receptor subtypes underlies many forms of reward-related behavior.

\section{REFERENCES}

ANDEN, N. E. (1977). Functional effects of local injections of dopamine and analogs into the neostriatum and nucleus accumbens. In E. Costa \& G. L. Gessa (Eds.), Aduances in biochemical psychopharmacology (pp. 385-389). New York: Raven Press.

ANDERSEN, P. H., JANSEN, J. A. (1990). Dopamine receptor agonists: Selectivity and dopamine D2 receptor efficacy. European Journal of Pharmacology, 188, 335-347.

BENINGER, R. J. (1983). The role of dopamine in locomotor activity and learning. Brain Research Reviews, 6, 173-196.

Beninger, R. J., Hanson, D. R., \& Phillips, A. G. (1981). The acquisition of responding with conditioned reinforcement: Effects of cocaine, (+)-amphetamine and pipradrol. British Journal of Pharmacology, 74, 149-154.

Beninger, R. J., Hoffman, D. C., \& Mazurski, E. J. (1989). Receptor subtype-specific dopaminergic agents and conditioned behavior. Neuroscience \& Biobehavioral Reviews, 13, 113-122.

BindRA, D. (1968). Neuropsychological interpretation of the effects of drive and incentive-motivation on general and instrumental behavior. Psychological Review, 75, 1-22.

Bruning, J. L., KinTz, B. L. (1977). Computational handbook of statistics. Glenview, IL: Scott, Foresman.
CAdor, M., Robbins, T. W., \& Everutt, B. J. (1989). Involvement of the amygdala in stimulus-reward associations: Interaction with the ventral striatum. Neuroscience, 30, 77-86.

Cador, M., Taylor, J. R., Robbins, T. W. (1991). Potentiation of the effects of reward-related stimuli by dopaminergic-dependent mechanisms in the nucleus accumbens. Psychopharmacology, 104, 377-385.

CARr, G. D., White, N. M. (1983). Conditioned place preference from intra-accumbens but not intra-caudate amphetamine injections. Life Sciences, 33, 2551-2557.

ClARK, D., \& Wrte, F. J. (1987). Review: D1 dopamine receptor-the search for a function: A critical evaluation of the D1/D2 dopamine receptor classification and its functional implications. Synapse, 1. 347-388.

Delfs, J. M., Kelley, A. E. (1990). The role of D-1 and D-2 dopamine receptors in oral stereotypy induced by dopaminergic stimulation of the ventrolateral striatum. Neuroscience, 39, 59-67.

Delfs, J. M., Schreiber, L., \& Kelley, A. E. (1990). Microinjection of cocaine into the nucleus accumbens elicits locomotor activation in the rat. Joumal of Neuroscience, 10, 303-310.

Dreher, J. K., JACKson, D. M. (1989). Role of D1 and D2 dopamine receptors in mediating locomotor activity elicited from the nucleus accumbens in rats. Brain Research, 487, 267-277.

Ettenberg, A., Pettrt, H. O., Bloom, F. E., Коob, G. F. (1982). Heroin and cocaine intravenous self-administration in rats: Mediation by separate neural systems. Psychopharmacology, 78, 204-209.

Fuller, R. W., Hemrick-Luecke, S. K. (1985). Decrease in hypothalamic epinephrine concentration and other neurochemical changes produced by quinpirole, a dopamine antagonist, in rats. Journal of Neural Transmission, 61, 161-173.

Goeders, N. E., \& SMrTH, J. E. (1983). Cortical dopaminergic involvement in cocaine reinforcement. Science, 221, 773-775.

HILL, R. T. (1970). Facilitation of conditioned reinforcement as a mechanism of psychomotor stimulation. In E. Costa \& S. Garattini (Eds.), Amphetamine and related compounds (pp. 781-795). New York: Raven Press.

HillegaArt, V., \& Ahlenius, S. (1987). Effects of raclopride on exploratory motor activity, treadmill locomotion, conditioned avoidance behaviour and catalepsy in rats: Behavioural comparisons between raclopride, haloperidol, and preclamol. Pharmacology \& Toxicology, 60, 350-354.

HIROI, N., \& WHITE, N. M. (1991). The amphetamine conditioned place preference: Differential involvement of dopamine receptor subtypes and two dopaminergic terminal areas. Brain Research, 552, 141-152.

Hoebel, B. G., Monaco, A. P., Hernandez, L., Auluss, E., StanLEY, B. G., \& LENARD, L. (1983). Self-injection of amphetamine directly into the brain. Psychopharmacology, 81, 158-163.

Hoffman, D. C., Beninger, R. J. (1989). The effects of selective dopamine D1 or D2 receptor antagonists on the establishment of agonist-induced place conditioning in rats. Pharmacology, Biochemistry \& Behavior, 33, 273-279.

Hoffman, D. C., Dickson, P. R., Beninger, R. J. (1988). The dopamine D2 receptor agonists, quinpirole and bromocriptine produce conditioned place preferences. Progress in Neuropsychopharmacology \& Biological Psychiatry, 12, 315-322.

HuRD, Y. L., UNGERSTEDT, U. (1989). In vivo neurochemical profile of dopamine uptake inhibitors and releasers in rat caudate-putamen. European Joumal of Pharmacology, 166, 251-260.

Iorio, L. C., BArNett, A., LeITZ, F. H., Houser, V. P., Kordoba, C. A. (1983). SCH 23390 , a potential benzazepine antipsychotic with unique interactions on dopaminergic systems. Joumal of Pharmacology \& Experimental Therapeutics, 226, 462-468.

Kelley, A. E., Delfs, J. M. (1991). Dopamine and conditioned reinforcement: I. Differential effects of amphetamine microinjections into striatal subregions. Psychopharmacology, 103, 187-196.

Kelley, A. E., Delfs, J. M., Chu, B. (1990). Neurotoxicity induced by the D-1 agonist SKF 38393 following microinjection into rat brain. Brain Research, 532, 342-346.

KoOB, G. F., LE, H. T., * Creese, I. (1987). The DI dopamine receptor antagonist SCH 23390 increases cocaine self-administration in the rat. Neuroscience Letters, 79, 315-320.

Longoni, R., Spina, L., Di Chiara, G. (1987). Permissive role of 
D-1 receptor stimulation for the expression of D-2 mediated behavioral responses: A quantitative pharmacological study in rats. Life Sciences, 41, 2135-2145.

Lyness, W. H., Friedle, N. M., \& Moore, K. E. (1979). Destruction of dopaminergic nerve terminals in nucleus accumbens: Effects of d-amphetamine self-stimulation. Pharmacology, Biochemistry \& Behavior, 11, 553-556.

Markstein, R., Seiler, M. P., Vigoret, J. M., Urwyler, S., ENG, A., Dixon, K. (1988). Pharmacological properties of CY 208243, a novel D-1 agonist. In M. Sandler, A. Dahlstrom, \& R. Belmaker (Eds.), Progress in catecholamine research: Part B. Central aspects (pp. 59-64). New York: Alan R. Liss.

Molloy, A. G., O'Boyle, K. M., Pugh, M. T., \& Wadington, J. L. (1986). Locomotor behaviors in response to new selective D-1 and D-2 dopamine receptor agonists, and the influence of selective antagonists. Pharmacology, Biochemistry \& Behavior, 25, 249-253.

Murray, A. M., Waddington, J. L. (1990). New putative selective agonists at the D-1 dopamine receptor: Behavioural and neurochemical comparison of CY 208-243 with SKF 101384 and SKF 103243. Pharmacology, Biochemistry \& Behavior, 35, 105-110.

NaKAJIMA, S. (1989). Subtypes of dopamine receptors involved in the mechanism of reinforcement. Neuroscience \& Biobehavioral Reviews, 13, 123-128.

NAKAJima, S., \& BAKER, J. D. (1989). Effects of D2 dopamine receptor blockade with raclopride on intracranial self-stimulation and foodreinforced operant behaviour. Psychopharmacology, 98, 330-333.

Pellegrino, L. J., \& Cushman, A. J. (1967). A stereotaxic atlas of the rat brain. New York: Appleton-Century-Crofts.

Pettit, H. O., Ettenberg, A., Bloom, F. E., \& Koob, G. F. (1984). Destruction of dopamine in the nucleus accumbens selectively attenuates cocaine but not heroin self-administration in rats. Psychopharmacology, 84, 167-173.

Philups, A. G., Fibiger, H. C. (1990). Role of reward and enhancement of conditioned reward in persistence of responding for cocaine. Behavioral Pharmacology, 1, 269-282.

RoBbINS, T. W. (1975). The potentiation of conditioned reinforcement by psychomotor stimulant drugs. A test of Hill's hypothesis. Psychopharmacologia, 45, 103-114.

RoBbins, T. W. (1976). Relationship between reward-enhancing and stereotypical effects of psychomotor stimulant drugs. Nature, 264 57-59.

RobBins, T. W. (1978). The acquisition of responding with conditioned reinforcement: Effects of pipradrol, methylphenidate, d-amphetamine, and nomifensine. Psychopharmacology, 58, 79-87.

Robins, T. W., Cador, M., TAylor, J. R., Everitt, B. J. (1989). Limbic-striatal interactions in reward-related processes. Neuroscience \& Biobehavioral Reviews, 13, 155-162.

Robrins, T. W., EverIT, B. J. (1982). Functional studies of the central catecholamines. International Review of Neurobiology, 23, 305-365.

Roв8ins, T. W., « КоOв, G. F. (1978). Pipradrol enhances reinforcing properties of stimuli paired with brain stimulation. Pharmacology, Biochemistry \& Behavior, 8, 219-222.

Robbins, T. W., Watson, B. A., Gaskin, M., Ennis, C. (1983) Contrasting interactions of pipradrol, d-amphetamine, cocaine, co- caine analogues, apomorphine and other drugs with conditioned reinforcement. Psychopharmacology, 80, 113-119.

Roberts, D. C. S., Corcoran, M. E., Fibiger, H. C. (1977). On the role of ascending catecholaminergic systems in intravenous selfadministration of cocaine. Pharmacology, Biochemistry \& Behavior. 6, 615-620.

Roberts, D. C. S., Koob, G. F., Klonoff, P., Fibiger, H. C. (1980). Extinction and recovery of cocaine self-administration following 6-hydroxydopamine lesions of the nucleus accumbens. Pharmacology, Biochemistry \& Behavior, 12, 781-787.

SALAmONE, J. D. (1991). Behavioral pharmacology of dopamine systems: A new synthesis. In P. Willner \& J. Scheel-Kruger (Eds.), The mesolimbic dopamine system: From motivation to action (pp. 191 119). New York: Wiley.

SCHEEL-Kruger, J. (1971). Comparative studies of various amphetamine analogues demonstrating different interactions with the metabolism of the catecholamines in the brain. European Journal of Pharmacology, 14, 47-59.

TAYLOR, J. R., RoBBINS, T. W. (1984). Enhanced behavioural control by conditioned reinforcers following microinjections of damphetamine into the nucleus accumbens. Psychopharmacology, 84, $405-412$

TAYLOR, J. R., \& RoBBins, T. W. (1986). 6-Hydroxydopamine lesions of the nucleus accumbens, but not of the caudate nucleus, attenuate enhanced responding with reward-related stimuli produced by intraaccumbens d-amphetamine. Psychopharmacology, 90, 390-397.

Temlett, J. A., Chong, P. N., Oertel, W. H., Jenner, P., \& MARDSDEN, C. D. (1988). The D-1 dopamine receptor partial agonist, CY 208-243 exhibits antiparkinsonian activity in the MPTP-treated marmoset. European Journal of Pharmacology, 156, 197-206.

Walters, J. R., Bergstrom, D. A., Carlson, J. H., Chase, T. N., * BrAUN, A. R. (1987). D-1 dopamine receptor activation required for postsynaptic expression of D-2 agonist effects. Science, 236 , 719-722.

WHITE, F. J. (1987). D-1 dopamine receptor stimulation enables the inhibition of nucleus accumbens neurons by a D-2 receptor agonist. European Journal of Pharmacology, 135, 101-105.

White, N. M., Packard, M. G., Hirol, N. (1991). Place conditioning with dopamine D1 and D2 agonists injected peripherally or into the nucleus accumbens. Psychopharmacology, 103, 271-276.

Woolverton, W. L., Goldberg, L. I., \&inos, J. Z. (1984). Intravenous self-administration of dopamine receptor agonists by rhesus monkeys. Journal of Pharmacology \& Experimental Therapeutics, 230, 678-683

Woolverton, W. L., Virus, R. M. (1989). The effects of a D1 and a D2 dopamine antagonist on behavior maintained by cocaine or food. Pharmacology, Biochemistry \& Behavior, 32, 691-697.

YoKEL, R. A., WISE, R. A. (1976). Attenuation of intravenous amphetamine reinforcement by central dopamine blockade in rats. Psychopharmacology, 48, 311-318.

(Manuscript received November 1, 1991; revision accepted for publication February 26, 1992.) 